\title{
Modelling the potential winter distribution of the endangered Black-capped Vireo (Vireo atricapilla)
}

\author{
JORGE H. VEGA RIVERA, MIGUEL A. ORTEGA-HUERTA, SAHOTRA \\ SARKAR and JOHN H. RAPPOLE
}

\section{Summary}

We applied the ecological niche/habitat modelling approach to predict the potential winter distribution of the endangered Black-capped Vireo Vireo atricapilla. We used historical and current field records along with climatic and topographic variables to generate three different models (Biomapper, Maxent, and GARP). Using field data on species occurrence, a model was selected based on the accuracy of assessment results. A final model was obtained by eliminating those areas mapped as known unsuitable habitat, using high resolution land use/land cover data. The GARP model obtained the best accuracy values. It showed the winter distribution of the Black-capped Vireo to cover an area in western Mexico of about $141,000 \mathrm{~km}^{2}$ that runs along the Pacific coast from southern Sonora (Río Yaqui, Alvaro Obregón Dam) to the southern state of Oaxaca (Salina Cruz on the Pacific coast and Matias Romero, and inland). One third of the proposed model's area was located at elevations of o-500 m, while $83 \%$ occurred at elevations $<1,250 \mathrm{~m}$; however, a significant area $(17 \%)$ consists of sites $>1,250 \mathrm{~m}$ in elevation. For the most part, the distribution model proposed closely followed the tropical dry forest boundaries and clearly avoided temperate areas at higher elevations. This situation seems to be critical for the species, since the dry forest is one of most endangered Neotropical ecosystems, both nationally and internationally. Furthermore, the array of areas under protection regimes included only about $7.1 \%$ of the predicted wintering area. However, this figure could be misleading when it is considered that some protected areas are just "paper reserves" without significant conservation programmes developed in situ.

\section{Resumen}

En este estudio aplicamos los conceptos de nicho ecológico/modelado del hábitat para predecir la distribución invernal del Vireo atricapilla, una especie amenazada. Para esto, utilizamos registros de campo históricos y actuales, en combinación con variables climáticas y topográficas para generar tres modelos diferentes (Biomapper, Maxent, y GARP), de los cuales seleccionamos el mejor modelo mediante un análisis de precisión. El modelo final se obtuvo después de eliminar aquellas áreas con hábitat no adecuado para la especie, utilizando mapas de vegetación de alta resolución. El modelo GARP obtuvo los valores más altos de precisión. Este modelo muestra que la distribución potencial del Vireo atricapilla cubre un área en el oeste de México de $141,000 \mathrm{~km}^{2}$, a lo largo de la costa del Pacífico, desde el sur de Sonora (Río Yaqui, Presa Alvaro Obregón) hasta el sur del estado de Oaxaca (Salina Cruz en la costa del Pacífico y en Matías Romero, tierra adentro). Un tercio del área del área del modelo propuesto se localiza a altitudes de $0-500 \mathrm{~m}$, mientras que el $83 \%$ ocurre a elevaciones $<1,250 \mathrm{~m}$; sin embargo, un área significante $(17 \%)$ consiste de sitios localizados a altitudes $>1,250 \mathrm{~m}$. En su mayoría, el modelo de distribución propuesto sigue cercanamente los límites del bosque tropical seco, y evita claramente las zonas 
templadas, a elevaciones mayores. Esta situación puede ser crítica para la especie ya que a escala nacional e internacional, el bosque seco es una de los ecosistemas tropicales más amenazados. Además, el grupo de áreas naturales protegidas en la región propuesta incluye solamente el 7.1\% de la distribución potencia propuesta. Adicionalmente, esta figura podría aún ser menor cuando consideramos que muchas áreas con áreas de reserva que aunque decretadas oficialmente, no cuentan con programas de conservación desarrollados in situ.

\section{Introduction}

The Black-capped Vireo Vireo atricapilla is considered an endangered species in the United States (USFWS 1991) and Mexico (DOF 2002) because of its small population size and the relatively small area suitable for breeding (Grzybowski 1995). Currently, the species is undergoing a fiveyear status review (USFR 2005); a first formal evaluation provided current information on the species's distribution, population trends, and threats (USFWS 2007). Breeding habitat extends from central Oklahoma in the north through the Edward's Plateau and Big Bend National Park in Texas, to central Coahuila in Mexico. The primary threats for the species in the U.S. breeding area consist of habitat loss from development, exotic cattle grazing, and nest parasitism by Brown-headed Cowbirds Molothrus ater (Wilkins et al. 2006). The winter distribution, however, is not as well-documented. In their review of the status and distribution of this species, Wilkins et al. (2006) wrote, "The known non-breeding, winter range consists of an elongated and patchily distributed area along the Pacific slopes of the Sierra Madre Occidental Mountains in Mexico, extending from southern Sonora to Oaxaca".

Because events occurring during the non-breeding season play a critical role in the annual dynamics of migratory species (Rappole 1995, Marra and Holmes 2001), knowledge of winter habitat requirements is a high priority in the Black-capped Vireo Recovery Plan, and it is a prerequisite to further recovery efforts in Mexico (USFWS 1991). In fact, one of the recovery criteria consists of knowing if there is sufficient and sustainable habitat in the winter range to support the breeding populations (USFWS 1991).

In this study we apply an ecological niche/species distribution modelling approach (e.g. Guisan and Zimmermann 2000, Guisan and Thuiller 2005, Elith et al. 2006) to predict the potential nonbreeding distribution of the Black-capped Vireo. These techniques are being increasingly used in threatened species conservation to identify potential distributions and focus conservation action (e.g. Donald et al. 2010). Our goal was to generate a model of the species' distribution that could be used for further research and conservation efforts directed at this species.

\section{Methods}

\section{Study area}

The study area was defined by those ecoregions with documented occurrence of Black-capped Vireo. We used this approach because ecoregions are characterised by geographically distinct assemblages of natural communities, sharing similar environmental conditions and having a large majority of species critically interacting for their long-term persistence (Olson et al. 2001). Dry forest and subtropical thorn forest are or were the original ecosystems in $48 \%$ of the study area, while ecoregions with temperate vegetation formations (e.g. pine and pine-oak forests) represent $44 \%$.

\section{Field occurrence data}

As part of a larger project on the current distribution of endemic birds in the Pacific lowlands of Mexico, we visited several dry forest locations in the states of Jalisco, Colima, Michoacan, Guerrero, and Oaxaca. We concentrated our field work during the months of May-September to cover the breeding season of resident birds; however, some sites were visited during December 
when Neotropical migrants are already settled on winter territories (Rappole 1995). At each locality we conducted 8-12 point counts (presence/absence) following standard protocols (Hutto et al. 1986).

\section{Generating distribution models}

Wintering distribution models for the Black-capped Vireo were generated by applying three different presence-only prediction software programs: Biomapper (Ecological Niche Factor Analysis; Hirzel et al. 2002), Maxent (Maximum Entropy; Phillips et al. 2006), and GARP (Genetic Algorithm for Rule-setting Prediction; Stockwell and Peters 1999). We used three predictive approaches because Biomapper and Maxent provide explicit analyses of species' ecological niches, and because of GARP's wide use for modelling bird species. Our approach consisted of generating and evaluating different models from which to select a final model with maximum accuracy.

\section{Modelling approach implementation}

GARP was applied following the best model selection approach which minimises omission and commission errors (Anderson et al. 2003): 1o best binary models were summed and then, applying a conservative approach and previous modelling experiences (e.g. Ortega-Huerta and Peterson 2004), only the pixels with the highest agreement values (9 and 10) were taken as the predicted presence of the species. Considering the tendency of Maxent to over-fit (Phillips et al. 2006, Dudik et al. 2007, Peterson et al. 2007, Phillips and Dudik 2008), we used a regularisation multiplier of three, while applying the 10 percentile training presence for defining a prediction threshold (value $=17$ ) so that we reduced the risk of underestimating the areas included by the species ecological niche model (a maximum of $10 \%$ of occurrences would wrongfully be predicted; e.g. Pearson et al. 2007). Finally, Biomapper's habitat suitability model was obtained by using the median algorithm. Five factors explained $95 \%$ of information. The k-fold cross-tabulation which is an evaluation method suitable for models generated from small datasets (Hirzel et al. 2006) helped to define a prediction threshold (value $=5 \mathrm{I}$ ). Other parameters applied when running such software are shown in Appendix $\mathrm{S}_{1}$ in the online Supplementary Materials.

\section{Model training data}

Data on the occurrence of Black-capped Vireo were obtained from natural history museum databases, literature reviews and field surveys. A total of 29 locations spanning the period 19472006 were used to predict the potential distribution: 18 records from the Global Biodiversity Information Facility database (GBIF; htpp://www.gbif.net), six records from the literature, and five records from our field survey. The data from GBIF were from the following sources: Cornell Lab of Ornithology, 12 records; Museum of Vertebrate Zoology (UC Berkeley), I record; Instituto de Biologia, UNAM, 1 record; Natural History Museum University of Kansas, I record; Louisiana State University Museum of Natural Science, I record; University of Washington Burke Museum, I record; Los Angeles County Museum of Natural History, I record. Although 56 additional observations by Wilkins et al. (2006) are an important contribution to our knowledge of the current distribution of Black-capped Vireo, we could not use them because of their lack of a geographical location. Moreover, a great percentage of museum records are from the same or nearby localities, which prevents us from using them as independent records for modelling purposes.

\section{Environmental prediction variables}

We used seven climatic variables: mean diurnal temperature range, isothermality (mean diurnal range/ annual temperature range), annual precipitation, precipitation of driest month, 
precipitation seasonality, precipitation of warmest quarter, and precipitation of coldest quarter (Hijmans et al. 2005) and four topographical variables: aspect, elevation, slope and topographic index (referred to as wetness index because it is a function of the upstream contributing area and the slope of landscape; Moore et al.1991) (USGS 2005) as environmental prediction variables. We first generated distribution models based only on abiotic factors, such as climatic and topographic variables, and then restricted these models by eliminating areas covered by agriculture, improved grassland, and urban development which are known to be unsuitable habitats for the species. We used a high resolution up-to-date land use/land cover digital map provided by INEGI (2005).

\section{Model evaluation/selection}

Models generated by the three approaches were evaluated through an accuracy assessment which consisted of calculating the Kappa Index (Congalton and Green 1999, Jenness and Wynne 2004). Indeed, accuracy maximisation was the criterion applied for selecting a potential distribution model among the outputs obtained by the three modelling approaches. Species occurrence data used for model evaluation/selection consisted of field data provided by Hollon and Sarkar (2009). These data included 15 independent presence sites, corresponding to dates from February 2002 to February 2004. Pseudo-absence data were obtained by generating 15 random sites within areas modelled as species absence by comparing approaches; GARP absence areas were used to generate random sites to evaluate both Maxent and Biomapper models, and conversely, Maxent absence areas were used to generate random sites to evaluate the GARP model.

\section{Results}

We include in this report five unpublished field records by the authors. These records are summarised in Table $I$ and the localities and vegetation are described in Appendix $S_{2}$ in the online Supplementary Materials.

\section{Geo-referenced records from the literature}

Schaldach (1963: 75) observed two individuals in Colima (February 1958 "north slope of the Media Luna" (103 ${ }^{\circ} 58^{\prime} 11.9^{\prime} \mathrm{W}, 19^{\circ} 13^{\prime} 48^{\prime} \mathrm{N}$; $568 \mathrm{~m}$ a.s.l.; Davis (1960) reported one individual $15.5 \mathrm{~km}$ north-west of Manzanillo, Colima (104 $24^{\prime} 49^{\prime} \mathrm{W}, 19^{\circ} 08^{\prime} 22.3^{\prime} \mathrm{N}$; $138 \mathrm{~m}$ a.s.l.); Hutto (1994) reported two individuals in the lowlands of Jalisco on December 1984 at Estación de Biología Chamela (105 ${ }^{\circ} 2^{\prime} 44.7^{\prime} \mathrm{W}, 19^{\circ} 30^{\prime} 4.8^{\prime} \mathrm{N} ; 33 \mathrm{~m}$ a.s.l.); Binford (1989: 220) cited the Sierras de Mihuatlán and Yucuyacua in the state of Oaxaca as the south-easternmost locations of the vireo's winter range. He observed an individual (11 February 1974) at $914 \mathrm{~m}$ a.s.l. on a road $9.6 \mathrm{~km}$ north of Putla de Guerrero $\left(97^{\circ} 59^{\prime} 12.4^{\prime} \mathrm{W}, 17^{\circ} 03^{\prime} 16.4^{\prime} \mathrm{N}\right)$. Two females were collected on 8 and II December 1963, just north of San Gabriel Mixtepec ( $97^{\circ} 04^{\prime} 27 \cdot 4^{\prime} \mathrm{W}, 16^{\circ} 03^{\prime} 22.7^{\prime} \mathrm{N} ; 731 \mathrm{~m}$ a.s.l.) (Phillips 1966, cited in Binford 1989).

Table 1. Date and geographic location of the authors' unpublished winter field records of the Black-capped Vireo Vireo atricapilla.

\begin{tabular}{llllll}
\hline Date & Locality & State & Latitud W & Longitud N & Altitud \\
\hline 1o December 2005 & Huatulco & Oaxaca & $96^{\circ} \mathrm{O9}^{\prime} 48.2^{\prime}$ & $15^{\circ} 48^{\prime} 3.9^{\prime}$ & $111 \mathrm{~m}$ \\
9 September 2005 & Campo Cuatro & Colima & $103^{\circ} 51^{\prime} 28.8^{\prime}$ & $19^{\circ} 21^{\prime} 15.1^{\prime}$ & $1,351 \mathrm{~m}$ \\
7 December 2004 & La Garita & Jalisco & $103^{\circ} \mathrm{OO}^{\prime} 36^{\prime}$ & $19^{\circ} 28^{\prime} 22.8^{\prime}$ & $1,227 \mathrm{~m}$ \\
16 September 2004 & Campos & Colima & $104^{\circ} 19^{\prime} 40.8^{\prime}$ & $19^{\circ} 2^{\prime} 20.04^{\prime}$ & $133 \mathrm{~m}$ \\
22 March 2001 & EBCh, UNAM & Jalisco & $105^{\circ} \mathrm{O} 2^{\prime} 13.2^{\prime}$ & $19^{\circ} 30^{\prime} 20.5^{\prime}$ & $48 \mathrm{~m}$ \\
\hline
\end{tabular}




\section{Predicted potential wintering range}

According to our three models, potential wintering distribution consists of areas of about 115,590 $\mathrm{km}^{2}$ (Biomapper), 126,346 km² (Maxent), and 141,390 km² (GARP) (Figure 1). Each of these models represented a $c .30 \%$ reduction in area after masking out agriculture, urban areas, and improved grassland-land use/land cover types known to be unsuitable for the species. The intersection of the three binary models (presence/absence) resulted in a spatial correspondence of $83 \%(64 \%$ absence and $19 \%$ presence), while spatial disagreement in predicted presence consisted of $5 \%$ of the total area predicted exclusively by GARP, $3 \%$ by Biomapper and $2 \%$ by Maxent. Highest percentage of spatial agreement between pairs of models corresponded to GARP and Maxent with $91 \%$ (67\% absence and $24 \%$ presence). Results of the accuracy assessment showed that GARP and Maxent models had the highest Kappa values (o.86 and o.80, respectively; see Table 2), with non-significant differences between both models ( $Z=0.47 ; P=$ o.32). Based on these results, the GARP model was selected to identify areas considered as potential wintering range of Black-capped Vireo in Mexico.

The predicted winter distribution extends along the Pacific coast; its most northern limit is located in southern Sonora (Río Yaqui, Alvaro Obregón Dam), while the most southern areas are located in the state of Oaxaca (Salina Cruz on the Pacific coast and Matias Romero inland). Distribution patterns of the species are described in the first instance by ecoregions. However, to provide a more detailed description of predicted presence and absence boundaries we used physiographic regions (Cervantes-Zamora et al. 1990) which included the selected ecoregions (Figure 2):

a) Sinaloa Dry Forest especially restricted to Pie de la Sierra physiographic region.

b) Jalisco Dry Forest with the exception of Volcanoes de Colima southern slope and eastern slope of the Trans-Mexican Volcanic Belt Pine-oak forests.

c) Southern Pacific Dry Forest with exception of Sierras and Valles de Oaxaca.

d) Balsas Dry Forest especially its southern slopes neighbouring the Southern Pacific Dry Forests and the Sierra Madre del Sur Pine-oak Forests, and its northern areas next to the Trans-Mexican Volcanic Belt Pine-oak Forests, with the exception of its eastern and northern areas.

e) Low elevation areas within the Sierra Madre del Sur Pine-oak Forests.

Other areas of potential wintering range are less extensive in regions such as Llanura Costera de Mazatlán, Delta del Río Grande Santiago, southern Sierras y Valles Zacatecanos, Gran Meseta y Cañones Duranguenses eastern slope, northern Sierra de Jalisco, southern Sierras Orientales (Oaxaca), and Sur de Puebla. There are also physiographic regions with different climatic regimes that did not contain predicted habitat for the species, such as the Llanura Costera y Deltas de Sonora y Sinaloa in the arid realm; Altos de Jalisco, Chapala, Neovolcánica Tarasca and Volcanes de Colima in the temperate zone; and the Depresión del Tepalcatepec, Sierras Centrales de Oaxaca, Mixteca Alta, and Sierras y Valles de Oaxaca in the tropical semi-humid climatic zone.

For the most part, the predicted range closely follows the dry forest boundary and clearly avoids areas with the highest elevations within temperate ecoregions such as the Trans-Mexican Volcanic Belt Pine-oak Forests (Figure 2). However, the model also appears to avoid the lowest areas of the Balsas Dry Forest ecoregion. Less than half (35\%) of the predicted area is located at elevations of $0-500 \mathrm{~m}$, while $83 \%$ occurs $<1,250 \mathrm{~m}$ and $17 \%>1,250 \mathrm{~m}$. Vegetation types within the predicted range consist of $33 \%$ temperate forests (cloud forest, pine, pine-oak and oak forests), $64 \%$ tropical deciduous and semi-deciduous forests, $<2 \%$ tropical evergreen and semievergreen forests, $<_{1} \%$ gallery forest and mangrove, and $<_{1} \%$ desert scrub.

Both Maxent and Biomapper identified elevation and seasonality of precipitation as the most useful of the 11 variables used in generating the distribution models. The environmental variables predicting the largest areas of the Black-capped Vireo's wintering range are shown in Table 3. These can be summarised as: areas at lower elevations and with lower values of mean diurnal temperature range, compared to values for the whole study area. On the other hand, both 

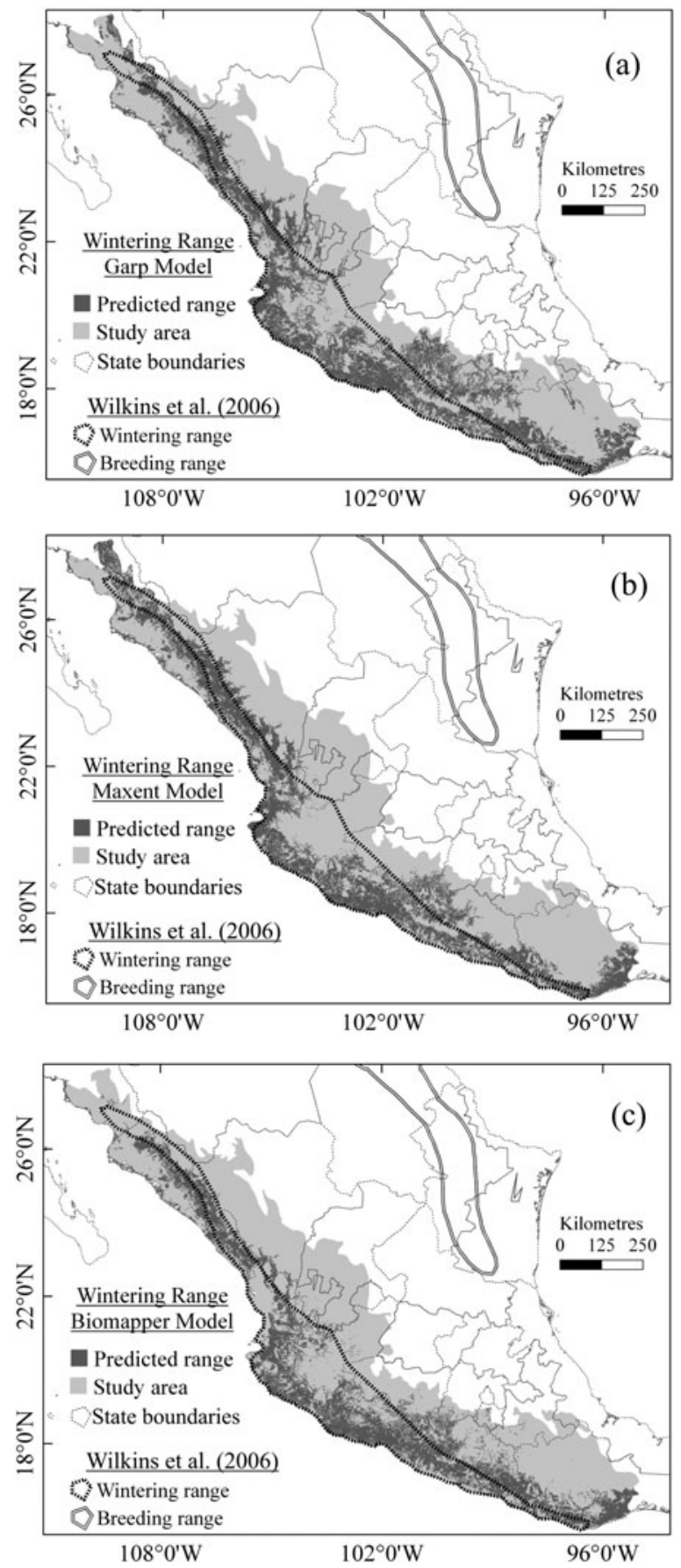

Figure 1. Black-capped Vireo winter range models, generated by three modelling approaches; (a) GARP, (b) Maxent, and (c) Biomapper. High resolution and updated land use/land cover data (INEGI 2005) was used to mask out areas known to be unsuitable for the species (e.g., agriculture, urban areas, improved grassland). The documented distribution polygon (Wilkins et al. 2006) is included for comparative purposes. 
Table 2. Accuracy assessment (Kappa Index) results for Black-capped Vireo's wintering distribution models, based on applying three modelling approaches (Biomapper, GARP and Maxent).

\begin{tabular}{lllll}
\hline Model & Overall accuracy & Overall miss-classification rate & KHAT & $P$-Value \\
\hline Biomapper & $(23 / 30)=0.76$ & $(7 / 30)=0.23$ & 0.53 & 0.0003 \\
GARP & $(28 / 30)=0.93$ & $(2 / 31)=0.06$ & 0.86 & 0.0000 \\
Maxent & $(27 / 30)=0.90$ & $(3 / 30)=0.10$ & 0.80 & 0.0000 \\
\hline
\end{tabular}

seasonality of precipitation and precipitation during the warmest part of the year had much higher values for the predicted range than average conditions for the whole region.

\section{Potential winter habitat and protected areas}

By the year 2002, there were only a few protected areas located within the Black-capped Vireo's predicted wintering range (CONANP 2002, CONANP 2005, Figure 3a): four biosphere reserves (Chamela-Cuixmala in Jalisco, Sierra de Manantlán in Jalisco and Colima, Sierra de Huautla in Morelos, Puebla and Guerrero, and Tehuacán-Cuicatlán in Puebla and Oaxaca), three national parks (El Veladero in Guerrero, Huatulco in Oaxaca, and Lagunas de Chacahua in Oaxaca) and two wildlife protection areas (Sierra de Alamos-Río Cuchujaqui in Sonora and Meseta de Cacaxtla in Sinaloa) covering a total of $2,229 \mathrm{~km}^{2}$ or $1.6 \%$ of the predicted winter distribution of the species. Recently, large watersheds distributed across Mexico's western slope were listed as natural protected areas by the Mexican government (CONANP 2009), and therefore the area within the vireo's predicted winter distribution that is protected increased to $7.1 \%$ (Table 4 and Figure $3 b$ ).

Finally, it is important to mention that nine Important Bird Areas (IBA) which amount to $14,924 \mathrm{~km}^{2}$ (Arizmendi and Márquez 2000) are also included within the vireo's predicted

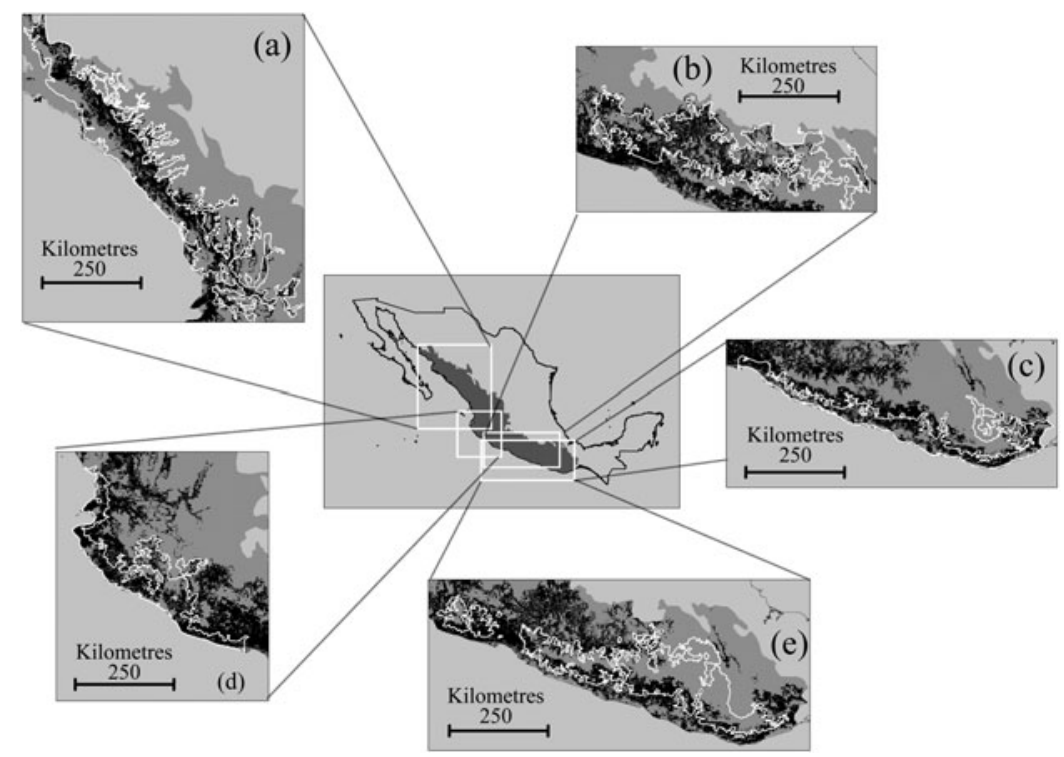

Figure 2. Proposed final model (GARP) of Black-capped Vireo's winter range in Mexico related to main ecoregions (Olson et al. 2001): (a) Sinaloan dry forest, (b) Balsas dry forest, (c) Southern Pacific dry forest, (d) Jalisco dry forest, and (e) Sierra Madre del Sur pine-oak forest. 
Table 3. Environmental variables used in the model that predict the largest areas of the Black-capped Vireo's winter distribution.

\begin{tabular}{|c|c|c|}
\hline Variable & Value range & $\begin{array}{l}\text { Percentage of } \\
\text { predicted area }\end{array}$ \\
\hline \multirow[t]{3}{*}{ Elevation } & $0-500 \mathrm{~m}$ & 35 \\
\hline & $0-1,250 \mathrm{~m}$ & 83 \\
\hline & $>_{1,250 \mathrm{~m}}$ & 17 \\
\hline \multirow[t]{3}{*}{ Seasonality of precipitation (coefficient of variation) } & $<100$ & 8 \\
\hline & $100-120$ & 90 \\
\hline & $>120$ & 2 \\
\hline \multirow[t]{4}{*}{ Precipitation in the driest month } & $\mathrm{o}-4 \mathrm{~mm}$ & 73 \\
\hline & $5^{-8} \mathrm{~mm}$ & 23 \\
\hline & $9^{-12} \mathrm{~mm}$ & 3 \\
\hline & $>12 \mathrm{~mm}$ & 1 \\
\hline \multirow[t]{3}{*}{ Precipitation in warmest quarter } & $43-250 \mathrm{~mm}$ & 18 \\
\hline & $251-500 \mathrm{~mm}$ & 57 \\
\hline & $501-1,266 \mathrm{~mm}$ & 25 \\
\hline \multirow[t]{3}{*}{ Mean range of diurnal temperature (mean of monthly max-min) } & $9 \cdot 5-13.3^{\circ} \mathrm{C}$ & 32 \\
\hline & $13.4-17.1^{\circ} \mathrm{C}$ & 64 \\
\hline & $17.2-19.1^{\circ} \mathrm{C}$ & 4 \\
\hline \multirow[t]{3}{*}{ Isothermality } & $53-66$ & 51 \\
\hline & $67-80$ & 48 \\
\hline & $>80$ & 1 \\
\hline
\end{tabular}

wintering range. These are: Coalcomán-Pomaro $\left(2,500 \mathrm{~km}^{2}\right)$, Tumbiscatio $\left(1,565 \mathrm{~km}^{2}\right)$ and Cuenca Baja del Balsas $\left(1,130 \mathrm{~km}^{2}\right)$ in the state of Michoacán; Sierra de Atoyac $\left(929 \mathrm{~km}^{2}\right)$, Vallecitos de Zaragoza $\left(477 \mathrm{~km}^{2}\right)$ and Acahuizotla-Agua del Obispo $\left(419 \mathrm{~km}^{2}\right)$ in the state of Guerrero; Sierra de Miahuatlán $\left(746 \mathrm{~km}^{2}\right)$ in Oaxaca; Marismas Nacionales, $\left(1,160 \mathrm{~km}^{2}\right)$ in Nayarit-Sinaloa; and San Juan de Camarones $\left(1,291 \mathrm{~km}^{2}\right)$, Durango (Figure 3c).

\section{Discussion}

\section{Historical and predicted distribution}

The predicted winter distribution of the Black-capped Vireo, based on current observations (this study) and historical records, includes the states of Sinaloa, Nayarit, Jalisco, Colima, Michoacan, Guerrero and Oaxaca (Figure 2). These states have all been previously recorded as lying within the vireo's winter range (Miller et al. 1957: 220), although this source also reported birds from Durango (west of Sierra Madre) and the state of Mexico (Toluca volcano, as a regular winter resident). More recent records are those of Schaldach (1963) who observed two birds during his surveys in Colima and Jalisco. Hutto (1992) reported one observation during his intensive survey throughout western Mexico from Sinaloa to Chiapas. Villaseñor and Hutto (1995) observed one individual during their work in Jalisco, Colima, and Michoacan. Binford (1989) regarded the species as a rare winter resident in the Pacific region of Oaxaca. He cited records by Phillips (1966) in the Sierras de Mihuatlán and Yucuyacua in the state of Oaxaca as the southeasternmost locations in the vireo's winter range. We found it $40 \mathrm{~km}$ to the south of Phillips's (1966) records, in Arenoso Creek, Huatulco. To our knowledge, there are no winter records from south of this point. On the other hand, González-Medina et al. (2009) reported 15 new records from Sinaloa, where the species was not detected in the northern portions of the state.

Interestingly, at the Estacion de Biología Chamela, Jalisco, this vireo has been recorded four times. Hutto (1994) observed two individuals during his field work at the station from midNovember to mid-December 1984. Another individual was previously captured in the same area on 26 September of 1980 (IBUNAM \# Poo6oo5), and we captured one individual on 22 March 

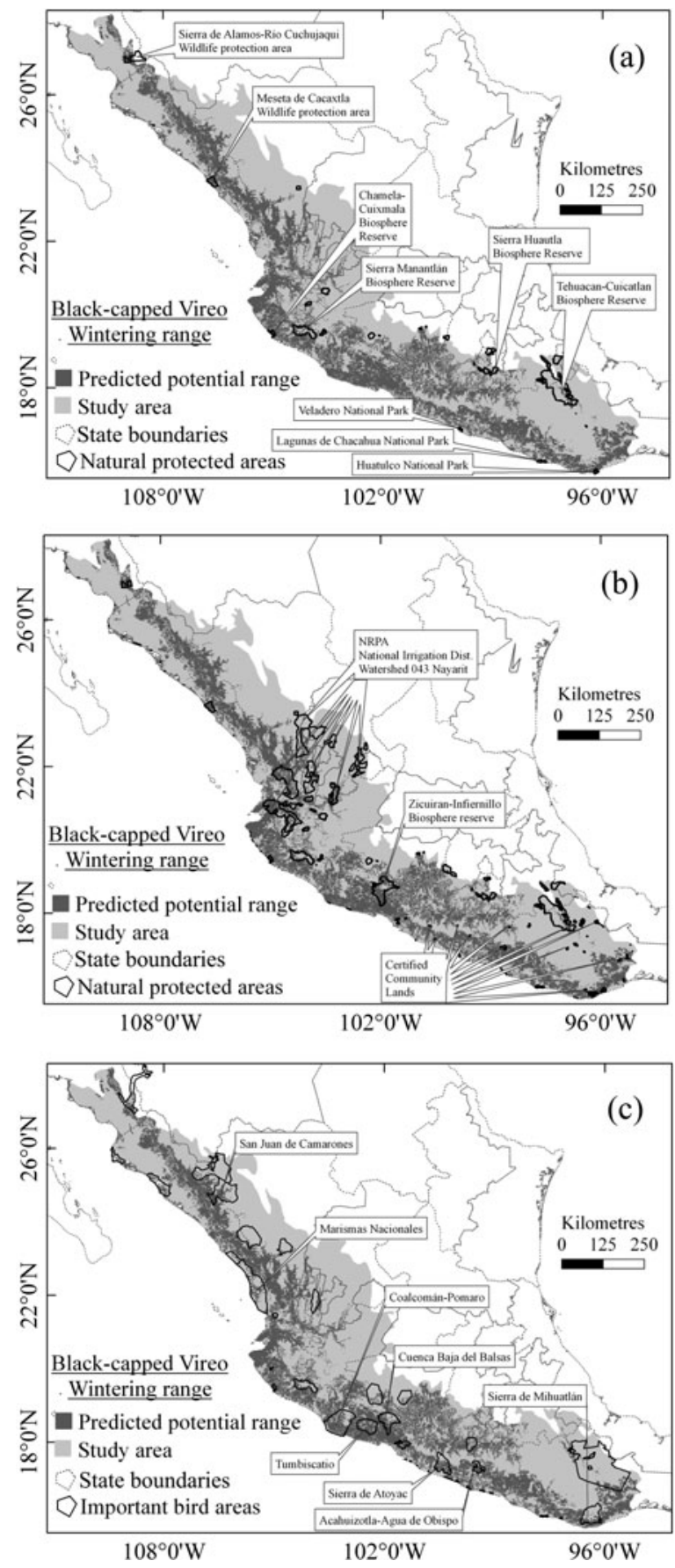

Figure 3. Proposed final model of the Black-capped Vireo's wintering range in Mexico, related to the natural protected areas (NPA) corresponding to the years 2002-2005 (a) and 2009 (b), and (c) Important Bird Areas (Arizmendi and Márquez 2000). 
Table 4. Predicted Black-capped Vireo wintering range included within current natural protected areas (NPA).

\begin{tabular}{lccl}
\hline Protection regime & $\begin{array}{l}\text { Area of predicted suitable } \\
\text { habitat included in current } \\
\text { NPAs }\left(\mathrm{km}^{2}\right)\end{array}$ & Percentage & $\begin{array}{l}\text { (Predicted } \\
\text { area in NPA/Total area } \\
\text { of predicted } \\
\text { wintering range) } \times 100\end{array}$ \\
\hline Wildlife Protection Areas & 754 & 7.5 & 0.53 \\
Natural Resources Protection Areas & 5,421 & 54.2 & 3.84 \\
Certified Community Lands & 239 & 2.4 & 0.17 \\
National Parks & 162 & 1.6 & 0.11 \\
Biosphere Reserves & 3,425 & 34.2 & 2.42 \\
Sanctuary & 0.08 & 0.0 & 0.0 \\
Total & 10,002 & 100 & 7.10 \\
\hline
\end{tabular}

2001. However, we cannot conclude that this species is common in the area. Intensive mistnetting and bird observations (point-counts) at the station during the temperate winter months (September-May) from 1999 to 2001, and 2005-2008, resulted in only one bird captured (J. Vega Rivera unpubl. data).

In the most recent review, Wilkins et al. (2006) recognised that the winter range of the Blackcapped Vireo had not been well documented. Based on previous reports, they delineated the wintering range along the Pacific slopes of the Sierra Madre Occidental Mountains in Mexico, extending from southern Sonora to Oaxaca, but concluded that most recent records (R. Powell unpubl. data) indicated that this vireo may be most heavily distributed in the states of Sinaloa (15 specimen records), Nayarit (13), Jalisco (seven) and Colima (two). González-Medina et al. (2009) reported 15 records from surveys during the winter months of 2004-2006. Previously, Graber (1961) found that most records were concentrated in Sinaloa and Nayarit and described this area as the centre of the wintering grounds. Other reported museum records include Durango (four), Michoacan (one), Guerrero (two), Oaxaca (three), and Mexico (one). More field work is needed to separate low/high occurrence from small/large sample effort, and accidental from expected distribution records.

\section{Winter range}

We generated three ecological niche models which showed similar geographic distribution patterns $(83 \%$ spatial correspondence among the three programs used - GARP, Maxent and Biomapper). Although the winter range proposed by Wilkins et al. (2006) was based on known locations since time of listing, a comparison between this study's distribution models and the former may be useful in revealing important geographical traits. The three models extended the range further to the north (except Biomapper) and to the south, beyond the documented occurrence of the species. In the south, the distribution runs along the southern coast (Costas del Sur province) and southern areas within the eastern sierras (Sierras Orientales province) in the state of Oaxaca.

Wilkins et al.'s (2006) winter range consists of a narrow elongated strip running to the south (e.g. southern coast), while our model also includes significant lower elevation areas located within the southern coastal mountains (Cordillera Costera del Sur province). This is especially true in the state of Oaxaca, while across the state of Guerrero, distributional areas belonging to the southern coastal mountains are located both at the transition zone with the southern coast and on this region's western slope, always avoiding higher elevations.

Wilkins et al.'s (2006) winter range widens most significantly in the middle part of Mexico's western slope, particularly in the states of Jalisco and Colima. However, our proposed distribution model shows that temperate regions included within such a wide distribution zone 
(Sierra de Jalisco, Chapala and Volcanes de Colima) contain no significant areas predicted as wintering range for the Black-capped Vireo. Finally, Wilkins et al.'s (2006) northern elongated range does not include the low elevation canyons and branches of the Sierra Madre shown by our proposed model.

According to updated high-resolution land use/land cover data (INEGI 2005), 99\% of the Black-capped Vireo's predicted winter distribution mainly includes tropical dry forests (64\%) and temperate vegetation formations (33\%). Gordon and Ornelas (2000) categorised the Blackcapped Vireo as an "apparent habitat generalist" based on different reports on its habitat preferences (Escalante 1988, Binford 1989, Howell and Webb 1995, Stotz et al. 1996). However, according to these authors, the dry forest seemed to be a recurring habitat type associated with the species; "tropical semi-deciduous forest" (Binford 1989: 220), "tropical deciduous forest" (Stotz et al. 1996: 282), "oak brush" and "tropical deciduous forest" (Escalante 1988), and "humid brushy second growth" and "forest edge" (Howell and Webb 1995). Further, Schaldach (1963), Davis (1960), Hutto (1994) and Villaseñor and Hutto (1995) associate this vireo with the dry forest, even though they visited other vegetation types. More recently, based on Powell's unpublished data, Wilkins et al. (2006) said that the Black-capped Vireo selects both mesic secondary growth and xeric scrub, but uses a variety of other habitat types, including shade coffee plantations, thorn forest, riparian forest, pine-oak forest and deciduous forest. In their survey in the State of Sinaloa, González-Medina et al. (2009) argue that the Black-capped Vireo shows a preference for the dry forests. We did find that this vireo can occur in disturbed habitats, but only to the degree that these places are located within a matrix of forested areas.

Based on our own observations, the predicted winter distribution, and analyses of the published information, we suggest that the Black-capped Vireo's winter habitat is primarily tropical dry forest, but it uses a variety of other habitat types and ecotones which occur and intermix with the tropical dry forest.

\section{Current status of tropical dry forest}

In Mexico, tropical dry forest ranges from sea level to 2,000 m (Miranda and Hernandez-X 1963; Rzedowski 1978, Trejo 1998). The dry forest (also known as deciduous forest, seasonal dry forest, tropical dry broadleaf forest, selva baja caducifolia, bosque tropical caducifolio) is the dominant vegetation type along the Pacific lowlands of Mexico, where it runs as a corridor from southern Sonora to Chiapas (Trejo and Dirzo 2000). Because this forest system occurs with, and becomes mixed with, fragments of semi-deciduous forest, thorn forest, desert scrub and oak forest at higher elevations, it is difficult to separate and evaluate its current actual extent and condition (Trejo 1998). One of the most recent analyses of the status of dry forest in Mexico is that of Trejo and Dirzo (2000). These authors concluded that by 1990 at a national level, only $27 \%$ of the original area of dry forest (around $14 \%$ of the country) remained intact, $27 \%$ was altered, $23 \%$ degraded, and the remaining $23 \%$ had been replaced by other land uses. Furthermore, the semideciduous forest which apparently plays an important role in maintaining the biological diversity of the dry forest (Stiles 1983), and which seems to be an important habitat for the Black-capped Vireo, is vanishing from the Pacific lowlands. This vegetation has been almost entirely replaced by agricultural fields and cattle-raising. Remnants of this vegetation type are restricted to rough terrain such as canyons and creeks (Lott et al. 1987). Mexico's dry forest is considered one of the most threatened among ten tropical and subtropical dry forest ecoregions (Miles et al. 2006).

Although the dry forest has been recognised as a global priority for protection (Murphy and Lugo 1986, Janzen 1988, Stotz et al. 1996, Olson et al. 2000) in Mexico and elsewhere, it has received very little attention in terms of research or conservation action (Noguera et al. 2002). There were recently only nine natural protected areas (NPA) covering about $1.6 \%$ of the Blackcapped Vireo's predicted winter distribution. The inclusion in 2009 of additional wild lands to the Natural Protected Areas System increased the area protected to $7.1 \%$. Such an increase results 
from adding large areas such as the Natural Resources Protection Area "Cuenca Alimentadora del Distrito de Riego 043 Estado de Nayarit" (54\% of the total predicted habitat within current NPA) and the Zicuirán-Infiernillo Biosphere Reserve, which together with existing biosphere reserves accounted for $34 \%$ of the total predicted habitat within current NPA (see Figure $3 \mathrm{a}-\mathrm{b}$ ). The remaining $12 \%$ of predicted habitat under official protection corresponds to areas for Wildlife Protection (7.5\%), National Parks (1.6\%), Natural Sanctuaries and Community Lands certified for conservation $(2.4 \%)$ (Figure $3 \mathrm{~b}$ ). The whole set of NPA containing predicted wintering range includes higher proportions of tropical deciduous forests, compared to available habitat; $72 \%$ of tropical deciduous and semi-deciduous forests (vs. $64 \%$ of total available), and $27 \%$ of temperate forests (vs. $33 \%$ of total available).

In contrast to the small extent of current protected areas, the identified IBAs cover a total of $14,924 \mathrm{~km}^{2}$ of predicted range. However, it seems the IBAs have been useful only as an academic exercise; the lack of resources and planning efforts has resulted in the absence of conservation programmes or actions within such areas. In their analysis of Neotropical birds Stotz et al. (1996: 51) wrote, "It is dangerous to be a deciduous specialist in the Neotropics". This conclusion appears to apply to the Black-capped Vireo in the non-breeding season. We believe our results can be used in identifying and evaluating specific key areas for the species during the non-breeding winter season. Our study also highlights the lack of information on the ecology of the Black-capped Vireo during the non-breeding season. Although our data are not conclusive, there is the possibility that this vireo is a participant in mixed-species flocks. Confirmation of this finding is extremely important for understanding the species's winter ecology, population biology, and conservation prospects.

\section{Supplementary Material}

The supplementary materials for this article can be found online at journals.cambridge.org/bci

\section{Acknowledgements}

We thank Rocio Guerrero and Andres Garcia for his help in the field. Logistical support (vehicles, equipment and office space) was provided by Estacion de Biología Chamela, Instituto de Biología, UNAM. We thank Simon Gilling, Tomislav Hengl, and two anonymous reviewers for insightful comments that greatly improved the manuscript. Funding for fieldwork was provided by UNAM though the Programa de Apoyo a Proyectos de Investigación e Innovación Tecnológica, (PAPIIT IN218803) to JV and MO.

\section{References}

Anderson, R. P., Lew, D. and Peterson, A. T. (2003) Evaluating predictive models of species' distributions: criteria for selecting optimal models. Ecol. Model. 162: 211232.

Arizmendi, M. C. and L. Márquez Valdelamar, eds. (2000) Áreas de importancia para la conservación de las aves de México. México, DF: CONABIO.

Binford, L. C. (1989) A distributional survey of the birds of the Mexican state of Oaxaca. Ornith. Monogr. 43: 1-418.
Cervantes-Zamora, Y., Cornejo-Olguín, S. L., Lucero-Márquez, R., Espinoza-Rodríguez, J. M., Miranda-Viquez, E. and PinedaVelázquez, A. (1990) Provincias fisiográficas de México. Atlas de México, Tomo II, Mapa General IV. Mapas 1o Regionalización Física, Clasificación de Regiones Naturales. México DF: Instituto de Geografía, U.N.A.M. CONANP (2002). Áreas naturales protegidas 3ra Edición, México DF: Comisión Nacional de Áreas Naturales Protegidas. [http:// www.conanp.gob.mx]. 
CONANP (2005) Áreas naturales protegidas federales de México. Edición 2005. Morelia, Michoacán de Ocampo, México: Comisión Nacional de Áreas Naturales Protegidas. [http://www.conanp.gob.mx/sig/].

CONANP (2009) Áreas naturales protegidas federales de México. Edición 2008. Morelia, Michoacán de Ocampo, México: Comisión Nacional de Áreas Naturales Protegidas. [http://conanp.gob.mx/sig/].

Congalton, R. and Green, K. (1999) Assessing the accuracy of remotely sensed data: Principles and practices. Boca Raton, FL: Lewis Publishers.

Davis, J. (1960) Notes on the birds of Colima, Mexico. Condor 62: 215-219.

DOF (Diario Oficial de la Federación) (2002) Norma Oficial Mexicana NOM-059ECOL-2001, Protección ambiental-especies nativas de México de flora y fauna silvestres

- Categorías de riesgo y especificaciones para su inclusión, exclusión o cambio - Lista de especies en riesgo. Mexico DF: Diario Oficial de la Federación, Estados Unidos Mexicanos. 6 de marzo del 2002.

Donald, P. F., Buchanan, G. M., Collar, N. J., et al. (2010) Rapid declines in habitat quality and population size of the Liben (Sidamo) Lark Heteromirafra sidamoensis necessitate immediate conservation action. Bird Conserv. Int. 20: 1-12.

Dudik, M., Phillips, S. J. and Schapire, R. E. (2007) Maximum entropy density estimation with generalized regularization and an application to species distribution modeling. J. Mach. Learn. Res. 8: 1217-1260.

Elith, J., Graham, C. H., Anderson, R. P., Dudík, M., Ferrier, S., Guisan, A., Hijmans, R. J., Huettmann, F., Leathwick, J. R., Lehmann, A., Li, J., Lohmann, L. G., Loiselle, B. A., Manion, G., Moritz, C., Nakamura, M., Nakazawa, Y., Overton, J. McC., Peterson, A. T., Phillips, S. J., Richardson, K., Scachetti-Pereira, R., Schapire, R. E., Soberón, J., Williams, S., Wisz, M. S. and Zimmermann, N. E. (2006) Novel methods improve prediction of species' distributions from occurrence data. Ecography 29: 129151.

Escalante, P. (1988) Aves de Nayarit. Mexico DF: U.A.N. y Museo de Zoología de la Facultad de Ciencias, U.N.A.M.
González-Medina, E., Angulo-Gastélum, U. T., Castillo-Guerrero, J. A. and GuevaraMedina, M. A. 2009. Distribución y abundancia relativa del vireo de cabeza negra (Vireo atricapilla) en Sinaloa, México. Ornitol. Neotrop. 20: 291-298.

Gordon, C. and Ornelas, J. F. (200o) Comparing endemism and habitat restriction in the Mesoamerican tropical deciduous forest birds: implications for biodiversity conservation planning. Bird Conserv. Int. Io: 289-303.

Graber, J. W. (1961) Distribution, habitat requirement, and life history of the Black-capped Vireo (Vireo atricapilla). Ecol. Monogr. 31: 313-336.

Grzybowski, J. A. (1995) Black-capped Vireo (Vireo atricapillus). No. 181 in A. Poole and F. Gill, eds. The birds of North America. Philadelphia, PA and Washington, DC: The Academy of Natural Sciences and The American Ornithologists' Union.

Guisan, A. and Thuiller, W. (2005) Predicting species distribution: offering more than simple habitat models. Ecol. Lett. 8: 993-1009.

Guisan, A. and Zimmermann, N. E. (200o) Predictive habitat distribution models in ecology. Ecol. Model. 135: 147-186.

Hijmans, R. J., Cameron, S. E., Parra, J. L., Jones, P. G. and Jarvis, A. (2005) Very high resolution interpolated climate surfaces for global land areas. Int. J. Climatol. 25: 19651978 .

Hirzel, A. H., Hausser, J., Chessel, D. and Perrin, N. (2002) Ecological-niche factor analysis: how to compute habitat-suitability maps without absence data. Ecology 83: 2027-2036.

Hirzel, A. H., Le Lay, G., Helfer, V., Randin, C. and Guisan, A. (2006) Evaluating the ability of habitat suitability models to predict species presences. Ecol. Model. 199:142-152.

Hollon, T. and Sarkar, S. (2009) Black-capped Vireo winter range occurrence data since 2000. Austin, Texas: University of Texas at Austin, Biodiversity and Biocultural Conservation Laboratory. (Technical Note 55).

Howell, S. N. G. and Webb, S. (1995) A guide to the birds of Mexico and northern Central America. New York: Oxford University Press. 
Hutto, R. L. (1992) Habitat distribution of migratory landbird species in western Mexico. Pp. 221-239 in J. M. I. Hagan and D. W. Johnston, eds. Ecology and conservation of Neotropical migrant landbirds. Washington, DC: Smithsonian Institution Press.

Hutto, R. L. (1994) The composition and social organization of mixed-species flocks in a tropical deciduous forest in western Mexico. Condor 96: 105-118.

Hutto, R. L., Pletschet, S. M. and Hendricks, P. (1986) A fixed-radius point count method for nonbreeding and breeding season use. Auk 103: 593-602.

INEGI (Instituto Nacional de Estadística Geografía e Informática). (2005) Conjunto de datos vectoriales de uso del suelo y vegetación, escala 1:250,000, Serie III (Continuo Nacional). México: Aguascalientes, Ags.

Janzen, D. H. (1988) Tropical dry forest: the most endangered major tropical ecosystem. Pp. ${ }^{130-137 ~ i n ~ E . ~ O . ~ W i l s o n, ~ e d . ~ B i o d i v e r-~}$ sity. Washington, DC: National Academy Press.

Jenness, J. and Wynne, J. J. 2004. Kappa analysis (kappa_stats.avx) extension for ArcView 3.x. Jenness Enterprises [http:// www.jennessent.com/arcview/

kappa_stats.htm].

Lott, E., Bullock, S. H. and Solis Magallanes, J. A. (1987) Floristic diversity and structure of upland and arroyo forest in coastal Jalisco. Biotropica 19: 228-235.

Marra, P. P. and Holmes, R. T. (2001) Consequences of dominance-mediated habitat segregation in American redstarts during the nonbreeding season. Auk 118: 92-104.

Miles, L., Newton, A. C., DeFries, R. S., Ravilious, C., May, I., Blyth, S., Kapos, V. and Gordon, J. E. (2006) A global overview of the conservation status of tropical dry forests. J. Biogeogr. 33: 491-505.

Miller, A. H., Friedmann, H., Griscom, L. and Moore, R. T. (1957) Distributional checklist of the birds of Mexico. Part II. Pac. Coast Avif. 33: 1-436.

Miranda, F. and Hernández-X, E. (1963) Los tipos de vegetación de México y su clasificación. Bol. Soc. Botánica de México 28: 29-179.
Moore, I. D., Grayson, R. B. and Ladson, A. R. 1991. Digital terrain modelling: A review of hydrological, geomorphological and biological applications. Hydrol. Process. January-March: 3-30.

Murphy, P. G. and Lugo, A. E. (1986) Ecology of tropical dry forest. Annu. Rev. Ecol. Syst. 17: 67-88.

Noguera, F. A., Vega Rivera, J. H., García Aldrete, A. N. and Quesada Avendano, M., eds. (2002) Historia natural de Chamela. México, DF: Instituto de Biología, Universidad Nacional Autónoma de México.

Olson, D. M., Dinerstein, E., Abell, R., Allnutt, T., Carpenter, C., McClenachan, L., D'Amico, J., Hurley, P., Kassem, K., Strand, H., Taye, M. and Thieme, M. (200o) The global 200: a representation approach to conserving the earth's distinctive ecoregions. Washington DC: World Wildlife Fund-US, Conservation Science Program.

Olson, D. M, Dinerstein, E., Wikramanayake, E. D., Burgess, N. D., Powell, G. V. N., Underwood, E. C., D'Amico, J. A., Itoua, I., Strand, H. E., Morrison, J. C., Loucks, C. J., Allnutt, T. F., Ricketts, T. H., Kura, Y., Lamoreux, J. F., Wettengel, W., Hedao, P. and Kassem, K. R. (2001) Terrestrial ecoregions of the world: A new map of life on Earth. BioScience 51: 933-938.

Ortega-Huerta, M. A. and Peterson, A. T. (2004) Modelling spatial patterns of biodiversity for conservation prioritization in northeastern Mexico. Divers. Distrib. Io: 39-54.

Pearson, R. G., Raxworthy, C. J., Nakamura, M. and Peterson, A. T. (2007) Predicting species distributions from small numbers of occurrence records: a test case using cryptic geckos in Madagascar. J. Biogeogr. 34: 102-117.

Peterson, T. A., Papes, M. and Eaton, M. (2007) Transferability and model evaluation in ecological niche modeling: a comparison of GARP and Maxent. Ecography 30: 550-560. Phillips, A. R. (1966) Further systematic notes on Mexican birds. Bull. Brit. Orn. Club 86: 86-94.

Phillips, S. J. and Dudik, M. (2008) Modeling of species distributions with Maxent: new extensions and comprehensive evaluation. Ecography 31: 161-175. 
Phillips, S. J., Anderson, R. P. and Schapire, R. E. (2006) Maximum entropy modeling of species geographic distributions. Ecol. Model. 190: 231-259.

Rappole, J. H. (1995) Ecology of migrant birds, a neotropical perspective. Washington DC: Smithsonian Press.

Rzedowski, J. (1978) La vegetación de México, Mexico: Limusa.

Schaldach, W. J. (1963) The avifauna of Colima and adjacent Jalisco, Mexico. Proc. Western Foundation Vertebr. Zool. 1: 1-100.

Stiles, F. G. (1983) Birds. Pp. 502-544 in D. H. Janzen, ed. Costa Rican natural history. Chicago, USA: University of Chicago Press.

Stockwell, D. R. B. and Peters, D. P. (1999) The GARP modelling system: problems and solutions to automated spatial prediction. Int. J. Geogr. Inform. Syst. 13: 143-158.

Stotz, D. F., Fitzpatrick, J. W., Parker III, T. A. and Moskovits, D. K. (1996) Neotropical birds: ecology and conservation. Chicago, USA: University of Chicago Press.

Trejo, I., (1998) Distribución y diversidad de selvas bajas de México: relaciones con el clima y el suelo. PhD Thesis, Facultad de Ciencias, UNAM. México, D.F.

Trejo, I. and Dirzo, R. (200o) Deforestation of seasonally dry forest: a national and local analysis in Mexico. Biol. Conserv. 94: 133-142.

USFR (2005) United States Federal Register. Wednesday, February 2. Vol. 70, no. 21: $5460-5463$.
USFWS (1991) Black-capped Vireo (Vireo atricapillus) recovery plan. Albuquerque, New Mexico: United States Fish and Wildlife Service, Region 2. available at http://ecos. fws.gov/docs/recovery_plan/91093oh.pdf.

USFWS (2007) Black-capped Vireo (Vireo atricapilla); 5-year review: Summary and evaluation. United States Fish and Wildlife Service, Southwest Region. Available at http:// www.fws.gov/southwest/es/Documents/ R2ES/Black-capped_Vireo_5-year_Review_ FINAL_7-6-07.pdf.

USGS (2005) Hydrork elevation derivative database. United States Geological Survey, U.S. Department of the Interior. Available at http://edc.usgs.gov/products/elevation/ gtopozo/hydro/index.html.

Villaseñor, J. F. and Hutto, R. L. (1995) The importance of agricultural areas for the conservation of neotropical migratory landbirds in western Mexico. Pp. 59-80 in M. H. Wilson and S. A. Sader, eds. Conservation of neotropical migratory birds in Mexico. Orono, ME: Maine Agricultural and Forest Experiment Station. (Miscellaneous Publication 727).

Wilkins, N., Powell, R. A., Conkey, A. A. T. and Snelgrove, A. G. (2006) Population status and threat analysis for the Blackcapped Vireo. Texas, USA: Texas A\&M University, Department of Wildlife and Fisheries Sciences. (Report prepared for U. S. Fish and Wildlife Service, Region 2).

JORGE H. VEGA RIVERA*, MIGUEL A. ORTEGA-HUERTA

Estación de Biología Chamela, Instituto de Biología UNAM, Km. 59, Carr, 200 Barra de Navidad-Puerto Vallarta, Chamela, Jalisco, México.

SAHOTRA SARKAR

Biodiversity and Biocultural Conservation Laboratory, Section of Integrative Biology, University of Texas, Austin, Texas, USA.

JOHN H. RAPPOLE

Smithsonian Conservation and Research Center, Front Royal, VA, USA.

*Author for correspondence; e-mail jhoga@ibiologia.unam.mx

Received 11 September 2009; revision accepted 11 March 2010; Published online 11 August 2010 